\title{
The Internationalization Process of Born Global High Technology SMEs: The Moderating Role of Business and Social Networks
}

\author{
S. Batas ${ }^{1}$, and L. Liu ${ }^{2}$ \\ ${ }^{1}$ (The University of Edinburgh): University of Edinburgh Business School, Edinburgh, UK \\ ${ }^{2}$ (The University of Edinburgh): University of Edinburgh Business School, Edinburgh, UK
}

\section{S.Batas@ed.ac.uk, Ling.Liu@ed.ac.uk}

\begin{abstract}
This paper examines the moderating role of business and social networks in the internationalization process of born global high technology Small and Medium Sized Enterprises (SMEs) in the context of developed and emerging economies. We develop a conceptual model in which the relationship between the two types of networks and the internationalization process (speed, geographic scope and entry mode) is analysed. We conclude that both business and social networks contribute to faster internationalization and offer necessary knowledge on new market opportunities. Our model aligns with previous studies and depicts the important role that institutional networks, part of business networks in this study, play in the internationalization process. We suggest that policy makers and entrepreneurs of high technology SMEs should be encouraged to develop all the necessary mechanisms to support and enhance early internationalization.
\end{abstract}

Keywords - High technology SMEs, international entrepreneurship, internationalization process, networks

\section{INTRODUCTION}

This study intends to identify the moderating role of networks that help born global high technology SMEs to internationalize. The literature enables the development of a theoretical framework, which can be tested empirically in developed and emerging economies.

The aim of this research is to answer the question: how the internationalization of born global high technology SMEs is influenced by networks? Previous studies have identified the important role that networks play in enhancing the internationalization process of SMEs [1], [2]. Networking can provide SMEs with necessary knowledge and support in order to compete when they expand their operations in the international arena [3]. Equally, networks can be a valuable source for knowledge and identification of international opportunities, thus their role in motivating SMEs to enter foreign markets is paramount [4], [5].

A great number of scholars have highlighted that SMEs are the backbone of emerging economies, however, the extant literature on the internationalization of SMEs operating there is limited [6]-[8]. The field of International Entrepreneurship (IE) emerged in 1994 as a new and promising research area, but, limited studies have compared and examined IE in the context of developed and emerging economies. Reference [9] defined IE as: "a combination of innovative, proactive, and risk-seeking behaviour that crosses national borders and is intended to create value in organisations." Some scholars indicated that IE is a subset of International
Business and Entrepreneurship [10]-[12]. In spite of this, a number of researchers supported that IE lacks of a robust theoretical framework [10], [13]-[15].

Reference [12] identified a gap in the theory and more specifically in the examination of the Comparative Entrepreneurial Internationalization. Comparative Entrepreneurial Internationalization, which emerged in 2001, includes cross-border entrepreneurship, but includes few cross-country comparisons on entrepreneurship in developing markets [12].

Networks can assist SMEs scarcity of resources and enable early and fast internationalization [8], [9]. According to [16] firms should utilize these networks to benefit their internationalization. On the other hand, existing networks may act as a hindrance to enrich and broaden a firm's network relationships. Thus, the firm may not be able to identify new business opportunities that lie outside its existing network [17], [18].

Reference [19] proposed that empirical investigation is needed to advance the IE theory. Moreover, [20] suggested using the predominant theoretical frameworks in order to understand in-depth how small companies internationalize. Following their suggestion to help to narrow this gap the institutional and network theory will be used to develop our theoretical framework. Finally the research question is defined as:

RQ: What is the moderating role of networks in born global high technology SMEs' internationalization process in emerging and developed economies, if any?

The structure of the article is as follows. The paper begins with the explanation of the role of networks in existing literature, and based on this propositions are generated. The third section describes the relationship between the different variables presented in the conceptual model. The last section presents the concluded points, implications and direction for future research.

\section{LITERATURE REVIEW}

This part of the paper briefly introduces the key literature on the internationalization process and networks in the IE field, and helps to identify the role of networks, and the relationship between networks and internationalization process.

\section{A. Gradual internationalization versus born global firms}

Reference [21] came up with a new definition of IE: "International entrepreneurship is the discovery, enactment, evaluation, and exploitation of opportunities across national borders - to create future goods and 
services." The Uppsala model is mainly focused on traditional cross-border behaviour, not on accelerated internationalization or on entrepreneurial behaviour. On the other hand, some scholars found that technological changes enable entrepreneurs to establish firms that internationalize quickly [22].

Reference [23] categorised the two main existing views on the internationalization of SMEs in the gradual approach and the born global companies. The first category includes the Uppsala model, which is dynamic and is related to market knowledge and sales in geographically, culturally, economically close markets [24].

There is not a clear definition of what a born global firm is [24]. Over time and in different studies early internationalising firms have been given different names [25]: born globals [22], global start-ups (e.g., [26]), International New Ventures [9] and instant exporters (e.g., [20]).

Reference [27] stressed the importance of developing the necessary and appropriate resources that can assist early internationalization. In addition, [28] analysed the role of public policy in supporting and encouraging the internationalization of born global companies. Reference [29] emphasized on the important role of time on internationalization. They identified a gap on how companies react in different contexts that are related to macro influences such as political and economic changes.

Reference [31] described born globals as firms that continuously expand their operations geographically. The definition of born global firms includes companies with $25 \%$ of foreign sales out of the total turnover and those that internationalize within 3 years of their inception [24],[31], [32]. Reference [32] describes born global firms "as firms which have products with global market potential."

Reference [33] found that current entrepreneurship literature focuses on two main research questions: how and where entrepreneurs identify new opportunities that enhance the firm's growth. The why question in IE remains under-examined. Reference [34] identified that internationalization is a constant move over time, and that we could learn more from the observation of the International New Ventures operations.

In order to examine the internationalization process of born global high technology SMEs we consider three criteria: 1) the time that the first foreign sale or business development took place. This is calculated by subtracting the year of inception from the year where the company initiated its first business activities in a foreign market; the most common definition of a born global firm is six years within its establishment [35]. 2) The number of countries where the firm operates, which is defined by the geographical scope of the firm's activities in foreign markets [21], [36]. 3) The entry mode that firm chooses to enter a new foreign market.

\section{B. Networks}

SMEs as mentioned earlier may lack sufficient resources to rapidly internationalize. As a result, they are pushed to rapidly identify networks that have a positive impact on internationalization [8], [37]. It was highlighted in previous studies that networks influence the internationalization patterns of a company related to economic transactions with their customers [8], [38].

There is a difference between business networks and social networks. Social networks encompass the links of an entrepreneur with other people in the society level [39]. The definition of social networks according to [40] refers to a "collection of individuals who may not be known to each other and who, in some way contribute something to the entrepreneur, either passively, reactively or proactively whether specifically elicited or not." Business networks refer to the interfirm links [41].

Previous studies have associated social networks with international and national opportunity recognition, mobilization of resources [42] and access to tacit knowledge [43]. Social networks in emerging economies facilitate business activity and can have an impact on firms' performance and strategic choices [44]. Reference [45] stressed the gap in literature concerning the types of network ties, which are more or less important in distant institutional environments.

1) Networks and speed of internationalization: The most common definition of speed of internationalization, developed in empirical studies, refers to the difference between the firm's inception year and the year of the first international sale [9], [46]. For the purpose of this study we will use this definition because we will examine the internationalization process of high technology SMEs.

At a theoretical level, the speed of internationalization is defined by the first market entry in a foreign country or the first foreign outputs that are influenced by enabling forces like technology advancements, motivating forces such as competition, mediating forces like the entrepreneur's characteristics and moderating forces such as knowledge and networks [21].

Entrepreneurs who operate in emerging economies have limited access to international networks. If entrepreneurs in emerging economies are not connected to national networks, the internationalization process may be hindered and slower. Reference [47] found that internationalization could be better founded if strong interpersonal relationships are used. Previous research leads to the development of the propositions below.

Proposition 1: The access to international networks is positively related to the internationalization process of born global high technology SMEs.

Proposition 1a: Firms that operate in developed economies have better access to international networks compared to their counterparts in emerging economies. As a result high technology SMEs in developed economies have a speedier internationalization.

Reference [4] suggested that weak ties can provide firms with the possibility to act autonomously, and that can have a positive impact on their adaptability. 
Additionally, rapid internationalization can be influenced by both easy or a lack of access to international social networks [21].

2) Networks and resources: As stated earlier resource scarcity is the main impediment of SMEs in order to further develop their operations [48]. SMEs' expansion to foreign markets can be negatively affected by the lack of experiential knowledge and capital [49]. The literature has partly explained the important role of networks and their substitute as resources for SMEs [8], [9], [21]. Based on these ideas, the following propositions are developed.

Proposition 2: Resources offered by networks are positively associated with the internationalization of born global high technology SMEs.

Reference [17] suggested that SMEs are more likely to use limited a number of networks and depend on them. This results to less freedom on the part of SMEs that have to follow the goals of partners, which are resource-rich [50].

3) Networks and knowledge: [21] proposed that there are three types of firms that rely differently on knowledge and the resultant speed of internationalization. The first type includes traditional firms, which adapt wellunderstood technologies (Uppsala Model). The second type refers to knowledge-intensive firms that use complex knowledge to design a new product. These firms internationalize faster because they develop a competitive advantage. Finally, the third type encompasses knowledge-based firms, which use sophisticated knowledge and follow very fast internationalization patterns because they have a unique sustainable advantage [21].

Born global high technology SMEs offer products, which require unique knowledge, and their speed of internationalization is fast. It is important to highlight at this point, [38] research on software companies in Western countries, which proposed that networks could explain the internationalization process of the examined firms. Networks can also offer valuable information on regulations in foreign markets [1].

Reference [51] stressed the importance of having networks that can positively influence the time and mode of internationalization by providing necessary links and information on new markets. Based on these suggestions, a proposition is developed as follows.

Proposition 3: Knowledge on foreign markets derived from networks is positively associated with the internationalization of high technology SMEs.

Reference [52] found that firms which operate in emerging economies and specifically in Asia search to collaborate and use sustainable networks in order to assist them to internationalize. Networks in China are dominated from quanxi. The use of quanxi can become an impediment in the firm's internationalization strategies to expand [53].

4) Networks and different institutional environments: Market choice, entry mode and expansion strategies can be heavily influenced by institutional networks (i.e., government institutions and agencies). Additionally, these can mitigate the risk and cost of internationalization [53].

Reference [1] found that three sources of networking helped SMEs to grow international. Including institutions (government agencies), personal relations (relatives, colleagues), and business associates (owners, managers).

Previous models, which have tried to explain the internationalization process of born global firms, have not focused on the moderating role of both social and business networks in different institutional contexts. An institutional-based approach, used in international business, can help to explain how the institutional environment can influence the internationalization process of firms based on emerging economies [53], [54]. Reference [6] highlighted the impact of institutional changes and the speed of these changes on firms founded in emerging economies. The internationalization of firms operating in emerging economies is closely related to the opportunities offered in new foreign markets [55]. Institutions in emerging markets are not as well developed, so firms in an effort to overcome the institutional voids, use informal institutions including social networks [54]. Reference [41] found that social networks have less influence in emerging economies than in firms from mature economies. Based on these notions, the following proposition is generated.

Proposition 4: High technology SMEs in emerging economies with less developed institutions are more dependent on business networks than social networks.

5) Networks and geographic scope: The traditional internationalization process theory perceives geographic distance as an impediment for rapid internationalization [56]. Geographic distance is defined as the difficulty to comprehend how a foreign environment-market works [56]. However, born global firms are able to overcome the obstacle of the geographic distance as they enter distant markets [9], [32]. Furthermore, [57] proposed that social networks are able to offer knowledge regarding cultural differences when firms decide to enter psychic distant markets. The following proposition is developed, based on previous findings.

Proposition 5: Networks' knowledge on foreign markets is positively associated to the number of psychic distant markets that high technology SMEs enter.

According to the network theory, social networks do not play an important role when a firm enters a geographic distant market. Future research should examine the role of social networks in emerging economies.

6) Networks and entry mode: The market selection and entry mode choice are very crucial and depend on the internationalization orientation of the management team [56], [58]. Reference [59] supported the relationship between mode of internationalization and network links.

Born global firms in the high technology sector develop complex relationships with their business partners and use more complex and multiple entry modes, 
when they decide to enter new foreign markets [2]. Previous studies lead to the development of the following proposition.

Proposition 6: Networks are positively associated to high commitment entry mode choices. High technology SMEs from developed countries tend to more frequently follow high commitment entry mode decisions compared to their counterparts from emerging markets.

\section{THEORETICAL FRAMEWORK}

Our conceptual model follows the model developed by [21] and focuses on foreign outputs rather than foreign inputs. Reference [21] suggested that four forces can direct internationalization speed: 1) enabling; 2) motivating; 3) mediating; and 4) moderating. The enabling force assists the rapid internationalization some examples include the Internet and communications. The second force includes the motivating force of competition where the firm's competitors push the internationalization decision of entrepreneurs. The mediating force refers to opportunity recognition by the entrepreneurial actor or group. The opportunity recognition is paramount for exploiting international opportunities. Finally, the moderating force can be categorised to knowledge intensity and international network.

Our model (Fig. 1) captures the moderating role of business and social networks in the internationalization process. The developed propositions explain the positive and negative role of different aspects that influence the internationalization process in firm level. For example, the less developed institutional environment in emerging economies pushes SMEs to depend more on business than social networks. The proposed model should be tested in empirical studies and verify if the developed propositions are valid.

The contribution of our framework is that it offers a context free model to compare emerging and developed countries. Moreover, the framework presents the internationalization process in the context of: 1) the role of business and social networks; 2) the role of institutions; and 3) changes over time.

We believe that the concepts of speed, geographic scope and entry mode can provide an explanation for the internationalization output of high technology SMEs. These concepts can provide an explanation for how SMEs decide to internationalize their operations. These examined areas also provide an explanation how business and social networks moderate the internationalization process.

\section{DISCUSSION}

We argue that our model can be generalized both to developed and emerging economies, because its nature is country context free. Being a member of a social network can accelerate internationalization because the exchange knowledge and trust are perceived as a competitive advantage [8].

Reference [60] studied ICT SMEs and proposed that social networks are paramount for forming business networks and internationalizing their operations. In particular the rapidly changing environment pushes companies to internationalize in an early stage in order to exploit opportunities in foreign markets [61].

Previous studies found that the geographic scope is greater when a born global firm is more international (e.g., [30]). Many studies analysed the relationship between the born global firm's early and rapid internationalization with the entrepreneur's networks [47]. Reference [62] verified that social networks are more crucial for entrepreneurs who operate in developing countries than in developed countries given information asymmetry.

Reference [63] were surprised that very limited studies have examined the elements of entrepreneurial activity in emerging economies and compared them with those in mature economies.

Reference [20] has referred to the association between the use of networks and risk mitigation of SMEs internationalization. Reference [8] described the importance of connections and how those help SMEs to obtain the necessary knowledge on foreign markets and their importance to minimise the entry barrier problems.

According to [64] "markets are networks of relationships in which firms are linked to each other in various, complex and, to a considerable extent, invisible patterns." Hence insidership in relevant network(s) is necessary for successful internationalization.

Moreover, in unstable environments entrepreneurs try to sustain their businesses by attaining domestic legitimacy and using powerful personal networks [45], [64]. In particular, reference [60] supported that social and business networks can help ICT firms to maintain a competitive position when they enter new international markets. Finally, [25] demonstrated the importance of personal networks in born globals.

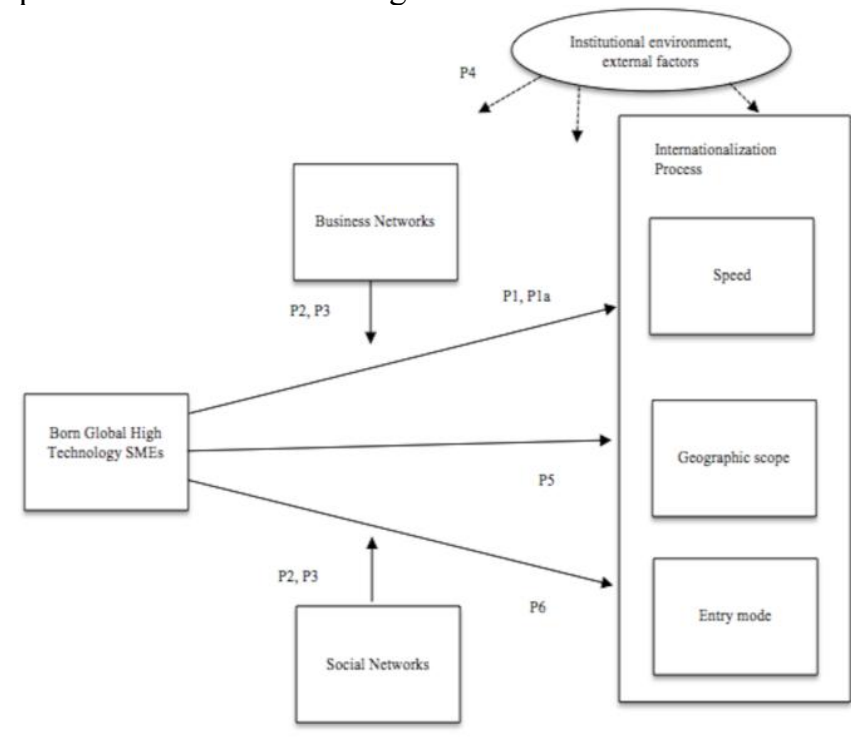

Fig. 1. Conceptual framework capturing the moderating role of networks in the internationalization process of high technology SMEs 


\section{CONCLUSION}

Policy makers should focus on firms that decide to internationalize in an early stage. They should encourage these companies to use networks and organize networking events. Government institutions should also support SMEs with tailored programs and market knowledge. The context of the high technology sector is global so the international contacts should be maximized. SME founders and managers should utilize diverse networks that offer them knowledge and access to necessary resources.

Future research should examine the importance of institutional networks in facilitating internationalisation of high technology SMEs. It would be very interesting to identify how born global high technology SMEs expand their operations internationally; and find how the environment that they operate influences their expansion patterns.

International entrepreneurship and entrepreneurship in emerging economies and more specifically a combination of these two categories are the most promising to advance the theory and explain the phenomenon of born-globals in developed and developing countries [10], [14], [33].

In conclusion, our study attempts to shed light on the role networks play in the internationalization process of high technology SMEs. The theoretical model and propositions developed herein can be tested empirically in future studies. Both qualitative and quantitative methods can be applied to further explore how networks influence the internationalization process of high technology SMEs that operate in developed and emerging economies.

\section{REFERENCES}

[1] Z. Che Senik, B. Scott-Ladd, L. Entrekin, and K. Adham, "Networking and internationalization of SMEs in emerging economies," J. of Int. Entr., vol. 9, pp. 259-281, 2011

[2] N. Coviello and H. Munro, "Network relationships and the internationalisation process of small software firms," Int. Bus. Rev., vol. 6, pp. 361-386, 1997.

[3] H. Etemad and Y. Lee, "The knowledge network of International Entrepreneurship: theory and evidence," Small Bus. Econ., vol. 20, pp. 5-23, Feb 2003

[4] D. D. Sharma and A. Blomstermo, "The internationalization process of born globals: a network view," Int. Bus. Rev., vol. 12, pp. 739-753, 2003.

[5] P. Ellis, "Social Ties and Foreign Market Entry," J. of Int. Bus. Stud., vol. 31, p. 443-469, 2000.

[6] G. D. Bruton, D. Ahlstrom, and K. Obloj, "Entrepreneurship in emerging economies: where are we today and where should the research go in the future," Entr. Theory and Practice, vol. 32, pp. $1-14,2008$.

[7] A. B. Sim and J. R. Pandian, "Emerging Asian MNEs and their internationalization strategies - case study evidence on Taiwanese and Singaporean firms," Asia Pacific J. of Manage., vol. 20, pp. 27-50, 2003.

[8] N. E. Coviello and H. J. Munro, "Growing the entrepreneurial firm: networking for international market development," European J. of Marketing, vol. 29, pp. 49-61, 1995.
[9] B. M. Oviatt and P. P. McDougall, "Toward a theory of international new ventures," J. of Int. Bus. Stud., vol. 25, pp. 45-64, 1994.

[10] A. Rialp, J. Rialp, and G. A. Knight, "The phenomenon of early internationalizing firms: what do we know after a decade (19932003) of scientific inquiry?," Int. Bus. Rev., vol. 14, pp. 147-166, 2005

[11] J. E. Coombs, F. Sadrieh and M. Annavarjula, "Two decades of international entrepreneurship research: what have we learned where do we go from here?" Int. J. of Entr., vol. 13, pp. 23-64, 2009.

[12] M. V. Jones, N. Coviello, and Y. K. Tang, "International Entrepreneurship research (1989-2009): a domain ontology and thematic analysis," J. of Bus. Venturing, vol. 26, pp. 632-659, Nov 2011.

[13] S. Young, P. Dimitratos, and L.-P. Dana, "International Entrepreneurship research: what scope for International Business theories?," J. of Int. Entrepr., vol. 1, pp. 31-42, 2003.

[14] M. M. Keupp and O. Gassmann, "The past and the future of International Entrepreneurship: a review and suggestions for developing the field," J. of Manage., vol. 35, pp. 600-633, Jun 2009

[15] A. N. Kiss, W. M. Danis, and S. T. Cavusgil, "International Entrepreneurship research in emerging economies: a critical review and research agenda," J. of Bus. Venturing, vol. 27, pp. 266-290, Mar 2012

[16] Y. K. Tang, "The influence of networking on the internationalization of SMEs: evidence from internationalized Chinese firms," Int. Small Bus. J., vol. 29, pp. 374-398, Aug 2011.

[17] S. Chetty and C. Campbell-Hunt, "Explosive international growth and problems of success amongst Small to Medium-Sized Firms," Int. Small Bus. J., vol. 21, pp. 5-27, Feb 2003.

[18] R. Gulati, N. Nohria, and A. Zaheer, "Strategic networks," Str. Manage. J., vol. 21, pp. 203-215, 2000.

[19] L. P. Dana and R. W. Wright, "International entrepreneurship: research priorities for the future," Int. J. of Global and Small Bus., vol. 3, no. 1, pp. 90-134, Jan 2009.

[20] N. E. Coviello and A. McAuley, "Internationalisation and the smaller firm: a review of contemporary empirical research," Manage. Int. Rev. (MIR), vol. 39, pp. 223-256, 1999.

[21] B. M. Oviatt and P. P. McDougall, "Defining International Entrepreneurship and modeling the speed of internationalization," Entr. Theory and Practice, vol. 29, pp. 537-554, 2005.

[22] G. A. Knight and S. T. Cavusgil, "The born global firm: a challenge to traditional internationalization theory," Advances in Int. Marketing, vol. 8, pp. 11-26, 1996.

[23] I. Kalinic and C. Forza, "Rapid internationalization of traditional SMEs: between gradualist models and born globals," Int. Bus. Rev. vol. 21, pp. 694-707, Aug 2012.

[24] O. Kuivalainen, S. Sundqvist, and P. Servais, "Firms' degree of born-globalness, international entrepreneurial orientation and export performance," J. of World Bus., vol. 42, pp. 253-267, Sep 2007.

[25] S. Andersson and F. Evangelista, "The entrepreneur in the born global firm in Australia and Sweden," J. of Small Bus. and Enter. Devel., vol. 13, pp. 642-659, 2006

[26] P. P. McDougall, S. Shane, and B. M. Oviatt, "Explaining the formation of international new ventures - the limits of theories from international-business research," J. of Bus. Venturing, vol. 9, pp. 469-487, Nov 1994

[27] Ø. Moen and P. Servais, "Born global or gradual global? Examining the export behavior of small and medium-sized enterprises," J. of Int. Marketing, vol. 10, pp. 49-72, 2002.

[28] J. Bell, R. McNaughton, and S. Young, "'Born-again global' firms: an extension to the 'born global' phenomenon," J. of Int. Manage. vol. 7, pp. 173-189, 2001.

[29] M. V. Jones and N. E. Coviello, "Internationalisation: conceptualising an entrepreneurial process of behaviour in time," $J$ of Int. Bus. Stud., vol. 36, pp. 284-303, May 2005.

[30] N. Hashai, "Sequencing the expansion of geographic scope and foreign operations by "born global" firms," J. of Int. Bus. Stud., vol. 42, pp. 995-1015, 2011

[31] G. A. Knight and S. T. Cavusgil, "Innovation, organizational capabilities, and the born-global firm," J. of Int. Bus. Stud., vol. 35, pp. 124-141, Mar 2004. 
[32] M. Gabrielsson, V. H. M. Kirpalani, P. Dimitratos, C. A. Solberg, and A. Zucchella, "Born globals: propositions to help advance the theory," Int. Bus. Rev., vol. 17, pp. 385-401, 2008.

[33] S.A Zahra and M. Wright, "Entrepreneurship's next act," Acad. Manage. Perspect., vol. 25, no. 4, pp. 67-83, Nov 2011.

[34] S. A. Zahra, "A theory of international new ventures: a decade of research," J. of Int. Bus. Stud., vol. 36, pp. 20-28, Jan 2005.

[35] B. M. Oviatt and P. P. McDougall, "Challenges for internationalization process theory: the case of international new ventures," Manage. Int. Rev., vol. 37, pp. 85-99, 1997.

[36] N. E. Coviello, "The network dynamics of international new ventures," J. of Int. Bus. Stud., vol. 37, pp. 713-731, 2006.

[37] J. Johanson and J.-E. Vahlne, "Business relationship learning and commitment in the internationalization process," J. of Int. Entr., vol. 1, pp. 83-101, 2003.

[38] J. Bell, "The internationalization of small computer software firms: a further challenge to "stage" theories," European J. of Marketing, vol. 29 , pp. 60-75, 1995.

[39] G. Shirokova and P. McDougall-Covin, "The role of social networks and institutions in the internationalization of Russian entrepreneurial firms: do they matter?," J. of Int. Entr., vol. 10, pp. 177-199, 2012.

[40] A. Gilmore and D. Carson, "Entrepreneurial marketing by networking," New England J. of Entr., vol.2, no. 2, pp. 31-38, 1999.

[41] P. D. Ellis, "Social ties and international entrepreneurship: Opportunities and constraints affecting firm internationalization," $J$ of Int. Bus. Stud., vol. 42, pp. 99-127, 2011.

[42] S. Shane and T. Stuart, "Organizational endowments and the performance of University start-ups," Manage. Sci., vol. 48, pp. 154-170, Jan 2002.

[43] T. Stuart and O. Sorenson, "The geography of opportunity: spatial heterogeneity in founding rates and the performance of biotechnology firms," Res. Policy, vol. 32, pp. 229-253, 2003.

[44] M. W. Peng and Y. Luo, "Managerial ties and firm performance in a transition economy: the nature of a micro-macro link," Acad. of Manage. J., vol. 43, pp. 486-501, June 2000.

[45] A. Kiss and W. Danis, "Social networks and speed of new venture internationalization during institutional transition: a conceptual model," J. of Int. Entr., vol. 8, pp. 273-287, 2010.

[46] A. R. Reuber and E. Fischer, "The influence of the management team's international experience on the internationalization behaviors of SMEs," J. of Int. Bus. Stud., vol. 28, pp. 807-825, 1997.

[47] S. Harris and C. Wheeler, "Entrepreneurs' relationships for internationalization: functions, origins and strategies," Int. Bus. Rev., vol. 14, pp. 187-207, 2005.

[48] T. E. Stuart, H. Hoang, and R. C. Hybels, "Interorganizational endorsements and the performance of entrepreneurial ventures," Admin. Sci. Quart., vol. 44, pp. 315-349, June 1999.

[49] L. C. Leonidou, "An analysis of the barriers hindering small business export development," J. of Small Bus. Manage., vol. 42, pp. 279-302, Jul 2004.

[50] S. Loane and J. Bell, "Rapid internationalisation among entrepreneurial firms in Australia, Canada, Ireland and New Zealand - an extension to the network approach," Int. Marketing Rev., vol. 23, pp. 467-485, 2006.

[51] J. Johanson and L. G. Mattsson, "Internationalization in industrial systems - a network approach," in Strategies in global competition, N. Hood and J. E. Vahlne, Ed. Croom Helm, London, 1988.

[52] M. Zeng and P. J. Williamson, "The hidden dragons," Harvard Bus. Rev., vol. 81, pp. 92-99, 2003.

[53] M. Zain and S. I. Ng, "The impacts of network relationships on SMEs' internationalization process," Thunderbird Int. Bus. Rev., vol. 48, pp. 183-205, 2006.

[54] M. Wright, I. Filatotchev, R. E. Hoskisson, and M. W. Peng, "Strategy research in emerging economies: challenging the conventional wisdom," J. of Manage. Stud., vol. 42, pp. 1-33, 2005.

[55] D. Ahlstrom and G. D. Bruton, "Rapid institutional shifts and the co-evolution of entrepreneurial firms in transition economies," Entr. Theory and Practice, vol. 34, pp. 531-554, 2010.

[56] J. Johanson and J.-E. Vahlne, "The internationalization process of the firm--a model of knowledge development and increasing foreign market commitments," J. of Int. Bus. Stud., vol. 8, pp. 2534, 1977.
[57] C. Styles and T. Ambler, "The impact of relational variables on export performance: an empirical investigation in Australia and the UK," Australian J. of Manage., vol. 25, pp. 261-281, Dec 2000.

[58] Ø. Moen, M. Gavlen, and I. Endresen, "Internationalization of small, computer software firms: entry forms and market selection," European J. of Marketing, vol. 38, pp. 1236-1251, 2004.

[59] S. Chetty and H. Agndal, "Social capital and its influence on changes in internationalization mode among small and mediumsized enterprises," J. of Int. Marketing, vol. 15, pp. 1-29, 2007.

[60] E. Vasilchenko and S. Morrish, "The role of entrepreneurial networks in the exploration and exploitation of internationalization opportunities by information and communication technology firms," J. of Int. Marketing, vol. 19, pp. 88-105, 2011.

[61] H. J. Sapienza, E. Autio, G. George, and S. A. Zahra, "A capabilities perspective on the effects of early internationalization on firm survival and growth," Acad. of Manage. Rev., vol. 31, pp. 914-933, Oct 2006.

[62] W. M. Danis, D. De Clercq, and O. Petricevic, "Are social networks more important for new business activity in emerging than developed economies? An empirical extension," Int. Bus. Rev. vol. 20, pp. 394-408, 2011.

[63] R. E. Hoskisson, L. Eden, C. M. Lau, and M. Wright, "Strategy in emerging economies," Acad. of Manage. J., vol. 43, pp. 249-267, 2000

[64] J. Johanson and J. E. Vahlne, "The Uppsala internationalization process model revisited: from liability of foreignness to liability of outsidership," J. of Int. Bus. Stud., vol. 40, pp. 1411-1431, 2009. 